\title{
The Influence of Correlation upon the Size of Leaves.
}

B Y

\author{
ALFRED J. EWART, D.Sc., Ph.D., F.L.S.
}

With two Figures in the Text.

CCORDING to Lindemuth ${ }^{1}$, leaves of Begonia rex and of Iresine
Lindeni which have been allowed to root in soil increase in size, and this increase is due not to any multiplication of cells but to an enlargement of the individual cells. It remains an open question whether the enlargement is directly due to a rise of turgor in the extensible cells of the leaf, or whether it is a true growth reaction awakened by some correlative influence. In any case it seemed of interest to determine whether a similar expansive enlargement can be produced on the leaves of an ordinary tree after they have ceased to grow, and a lime tree (Tilia europaea) was selected for the experiment.

On April I, all the buds were removed from a branch $145 \mathrm{cms}$. long and $2 \mathrm{cms}$. diameter at the base, excepting the terminal one, and new buds were removed as fast as they developed. The branch produced $3 \frac{1}{2}$ times as many buds as would normally develop. Measurements in centimetres of the leaves were taken on June 27 , the length and breadth of the lamina being those of an inscribing rectangle traced on paper (Fig. I). At the same time an average was taken of the larger leaves on normal shoots, and also of the smallest first formed ones.

Defoliated Branch.

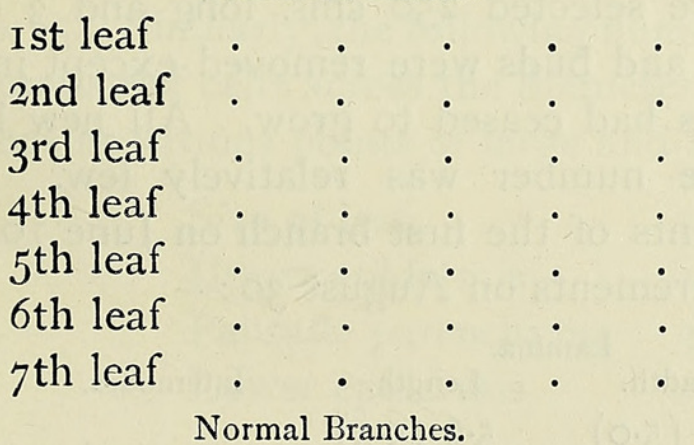

Average of largest adult leaves .

Average of smallest adult leaves

1 Ber. d. D. Bot. Ges., xxii, I904, p. I 7 I.
Lamina.

Petiole. Breadth. Length. Internode.

\begin{tabular}{|c|c|c|}
\hline 3 & $6 \cdot 2$ & \\
\hline $4 \cdot 5$ & $7 \cdot 8$ & 8. I \\
\hline $5 \cdot 2$ & I I 5 & I $4 \cdot 2$ \\
\hline $5 \cdot 0$ & I I $\cdot 2$ & I 5 \\
\hline $4 \cdot 2$ & I 2.5 & $\mathrm{I} 7 \cdot \mathrm{I}$ \\
\hline $3 \cdot 5$ & $13 \cdot 2$ & I $6 \cdot 2$ \\
\hline $2 \cdot 5$ & I 3.2 & 16.8 \\
\hline
\end{tabular}

$\begin{array}{rrrr}4 \cdot 4 & 7 \cdot 7 & \text { IO.I } & 4 \cdot 5^{2} \\ \text { I.5 } & 3.0 & 3.2 & 2 \cdot 8^{3}\end{array}$

2 Average on largest normal shoots.

3 Average on smallest normal shoots. 
All the leaves were now removed from the defoliated shoot except I and 2, which on August 30 measured:-

$\begin{array}{lccc} & \text { Petiole. } & \text { Breadth. } & \text { Laminath. } \\ \text { Ist leaf } & 3 & 6.3 & 7 \cdot 1 \\ \text { 2nd leaf } & 4.5 & 7.8 & 8.2\end{array}$

No increase in size had therefore occurred, since a difference of a millimetre is about the limit of error in measuring the lamina by this method, and the shape of the leaf precludes accurate direct measurement. Nevertheless, the removal of the lower buds in spring caused the remaining one to develop abnormally large leaves, as is well shown by the photograph reproduced in Fig. 2.

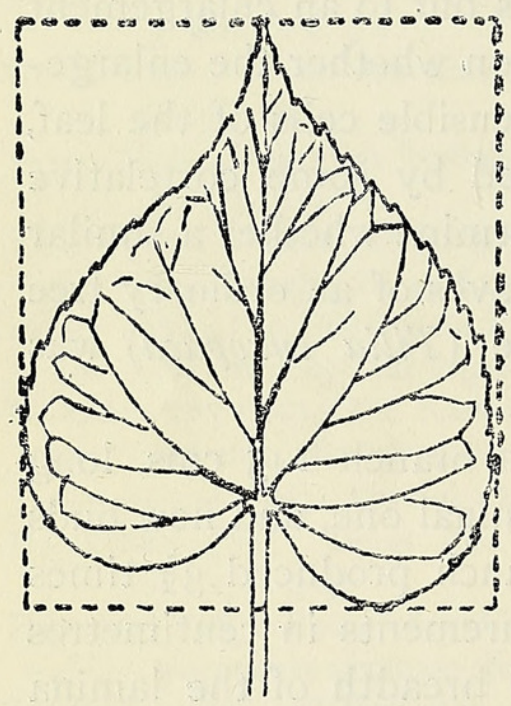

FIG. I. Mode of measurement of leaf.

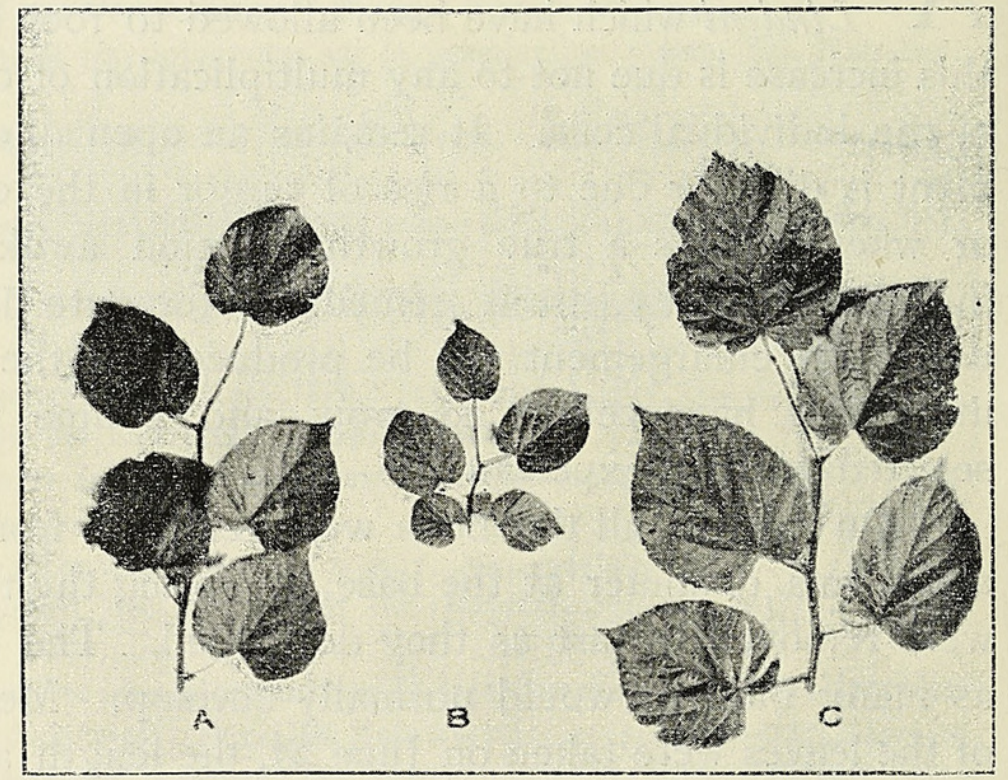

FIG. 2. A. Largest normal terminal shoot and leaves. B. Smallest ditto. C. Terminal shoot and leaves on defoliated branch. All from the same plant of Tilia europaea.

On June Io, two branches were selected $250 \mathrm{cms}$. long and $3 \mathrm{cms}$. thick at the base, and all the leaves and buds were removed except in the terminal shoot of each, whose leaves had ceased to grow. All new buds were continually removed, but the number was relatively few. The following figures give the measurements of the first branch on June 10 , the numbers in brackets being the measurements on August 30 :-

\begin{tabular}{|c|c|c|c|c|}
\hline & \multicolumn{4}{|c|}{ Lamina. } \\
\hline Ist leaf & I.9 (I.9) & $4 \cdot 7(5 \cdot 0)$ & $5 \cdot 6(5 \cdot 5)$ & $I . O(I . O)$ \\
\hline 2nd leaf & $2 \cdot 9(3 \cdot 0)$ & $6 \cdot 4(6 \cdot 5)$ & $7 \cdot 0(7 \cdot 1)$ & \\
\hline $3^{\text {rd leaf }}$ & $3.5(3.5)$ & $8.0(8.0)$ & $8.8(8.8)$ & \\
\hline $4^{\text {th }}$ leaf & $2 \cdot 8(3.0)$ & $7 \cdot 4(7 \cdot 5)$ & $9 \cdot 5(9 \cdot 5)$ & $\begin{array}{l}3.913 \\
2.2(2 .\end{array}$ \\
\hline $5^{\text {th }}$ leaf & $3 \cdot 0(3 \cdot 0)$ & $6 \cdot 0(6 \cdot I)$ & $7 \cdot 7(7 \cdot 8)$ & \\
\hline 6 th leaf & $2 \cdot 0(2 \cdot 0)$ & $5 \cdot 7(6 \cdot I)$ & $7 \cdot 2(7 \cdot 3)$ & \\
\hline
\end{tabular}


Apart from an apparent very slight increase in breadth which might easily be due to a greater divergence of the leaf teeth, or to a flattening of the lamina, no increase in size is shown.

The second branch had an erect glass tube filled with water attached to a side branch near to the apex, and on this branch and ultimately on a neighbouring one, a new surface was cut every second day for the entry of water. It was not found possible to maintain a greater pressure than Io ft. of water, since beyond this pressure the water passed backwards rapidly into the main trunk. A pressure of from 6 to $\mathrm{Io} \mathrm{ft}$. was, however, maintained for a month, and the measurements in brackets were taken on August 30 :-

\begin{tabular}{|c|c|c|c|c|}
\hline & \multicolumn{4}{|c|}{ Lamina. } \\
\hline & $\begin{array}{l}\text { Petiole. } \\
2 \cdot 3(2 \cdot 4)\end{array}$ & $\begin{array}{l}\text { Breadth. } \\
6.6(6.6)\end{array}$ & $\begin{array}{l}\text { Length. } \\
7 \cdot 5(7 \cdot 4)^{1}\end{array}$ & \\
\hline nd leaf & $2.9(2.9)$ & $7 \cdot 0(7 \cdot 0)$ & $8 \cdot 2(8 \cdot 2)$ & 0.7 \\
\hline rd leaf & $3 \cdot 3(3 \cdot 5)$ & $8.5(8.8)$ & I $0.0(9 \cdot 8)^{1}$ & \\
\hline h leaf & $3.3(3.5)$ & $8.5(8.6)$ & I I.2 $(1 \mathrm{I} \cdot 2)$ & \\
\hline th leaf & $3 \cdot 0(3 \cdot I)$ & $7 \cdot 8(8 \cdot 0)$ & IO.I $(10.4)$ & \\
\hline
\end{tabular}

Hence, neither the effect of an unusually abundant supply of water nor of the correlative influences due to the removal of the other buds and leaves are able to excite any renewed growth in an adult leaf of Tilia, even when acting conjointly. These influences, possibly aided by a more abundant supply of food, do, however, cause leaves to develop to an abnormally large size when applied at a sufficiently early period of their growth. The increased size is, however, not due to an increase in the size of the individual cells, but to an increase in their numbers.

Thus in sections of a leaf measuring $13.2 \times 16.8$ and of one measuring $6 \cdot I \times 7.4$ taken parallel to the midrib, the number of epidermal cells between the ends of a micrometer under the high power at various points was in both cases from 8 to $\mathrm{I} 2$, and of palisade parenchyma cells from 20 to 35 . Similarly, the following numbers give the maximal divergences in the number of cells across the diameter of the high power field in transverse sections at various points of large and small leaves :-

$\begin{array}{lll}\text { Size of leaf } & \text { I } 7.1 \times 12.5 & 3.5 \times 3 \\ \text { Upper epidermis } & \text { Io to I6 } & \text { I0 to I } 5 \\ \text { Palisade parenchyma } & 35 \text { to } 52 & 38 \text { to } 48 \\ \text { Lower epidermis } & \text { I I to I8 } & \text { I2 to I7 }\end{array}$

At corresponding points on the two leaves the numbers agreed very closely.

The facts first mentioned hardly agree with the usually accepted idea that the total number of leaf-cells is determined at an early date, and that

1 Tip slightly withered. 
82 Ewart. - The Influence of Correlation upon the Size of Leaves.

the subsequent expansion of the leaf merely involves an increase in their size, for the large dimensions shown by the leaves on the shoot defoliated in spring were attained owing to a longer continuance of growth, and to a larger production of cells during expansion. The absence of any power of response in the adult summer leaves is possibly correlated with the fact that the power of regenerative bud-development is much less pronounced in summer than it is in spring. 


\section{$2 \mathrm{BHL}$ Biodiversity Heritage Library}

Ewart, Alfred J. 1906. "The influence of correlation upon the size of leaves." Annals of botany $20,79-82$.

https://doi.org/10.1093/oxfordjournals.aob.a089084.

View This Item Online: https://www.biodiversitylibrary.org/item/234848

DOI: https://doi.org/10.1093/oxfordjournals.aob.a089084

Permalink: https://www.biodiversitylibrary.org/partpdf/318823

\section{Holding Institution}

Smithsonian Libraries

\section{Sponsored by}

Biodiversity Heritage Library

\section{Copyright \& Reuse}

Copyright Status: Not in copyright. The BHL knows of no copyright restrictions on this item.

This document was created from content at the Biodiversity Heritage Library, the world's largest open access digital library for biodiversity literature and archives. Visit BHL at https://www.biodiversitylibrary.org. 